\title{
Front Matter: Volume 11723
}

, "Front Matter: Volume 11723," Proc. SPIE 11723, Image Sensing Technologies: Materials, Devices, Systems, and Applications VIII, 1172301 (17 May 2021); doi: 10.1117/12.2598696

SPIE. Event: SPIE Defense + Commercial Sensing, 2021, Online Only 


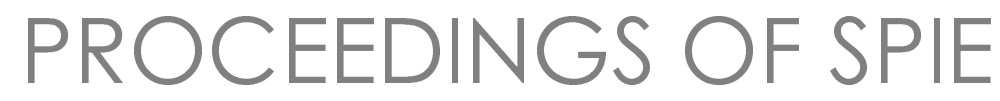

\section{Image Sensing Technologies: Materials, Devices, Systems, and Applications VIII}

Nibir K. Dhar

Achyut K. Dutta

Sachidananda R. Babu

Editors

12-16 April 2021

Online Only, Florida, United States

Sponsored and Published by

SPIE

Volume 11723 
The papers in this volume were part of the technical conference cited on the cover and title page. Papers were selected and subject to review by the editors and conference program committee. Some conference presentations may not be available for publication. Additional papers and presentation recordings may be available online in the SPIE Digital Library at SPIEDigitalLibrary.org.

The papers reflect the work and thoughts of the authors and are published herein as submitted. The publisher is not responsible for the validity of the information or for any outcomes resulting from reliance thereon.

Please use the following format to cite material from these proceedings:

Author(s), 'Title of Paper," in Image Sensing Technologies: Materials, Devices, Systems, and Applications VIII, edited by Nibir K. Dhar, Achyut K. Dutta, Sachidananda R. Babu, Proc. of SPIE 11723, Seven-digit Article CID Number (DD/MM/YYYY); (DOI URL).

ISSN: 0277-786X

ISSN: 1996-756X (electronic)

ISBN: 9781510642836

ISBN: 9781510642843 (electronic)

Published by

SPIE

P.O. Box 10, Bellingham, Washington 98227-0010 USA

Telephone +1 3606763290 (Pacific Time)

SPIE.org

Copyright @ 2021 Society of Photo-Optical Instrumentation Engineers (SPIE).

Copying of material in this book for internal or personal use, or for the internal or personal use of specific clients, beyond the fair use provisions granted by the U.S. Copyright Law is authorized by SPIE subject to payment of fees. To obtain permission to use and share articles in this volume, visit Copyright Clearance Center at copyright.com. Other copying for republication, resale, advertising or promotion, or any form of systematic or multiple reproduction of any material in this book is prohibited except with permission in writing from the publisher.

Printed in the United States of America by Curran Associates, Inc., under license from SPIE.

Publication of record for individual papers is online in the SPIE Digital Library.

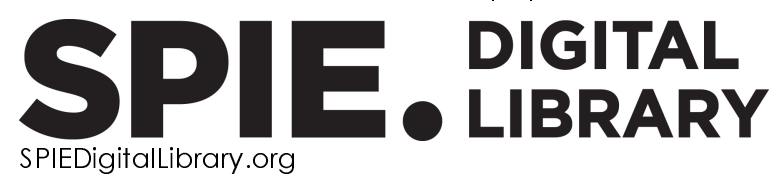

Paper Numbering: A unique citation identifier (CID) number is assigned to each article in the Proceedings of SPIE at the time of publication. Utilization of CIDs allows articles to be fully citable as soon as they are published online, and connects the same identifier to all online and print versions of the publication. SPIE uses a seven-digit CID article numbering system structured as follows:

- The first five digits correspond to the SPIE volume number.

- The last two digits indicate publication order within the volume using a Base 36 numbering system employing both numerals and letters. These two-number sets start with $00,01,02,03,04$, $05,06,07,08,09,0 A, 0 B \ldots$. OZ, followed by 10-1Z, 20-2Z, etc. The CID Number appears on each page of the manuscript. 


\section{Contents}

\section{SESSION 1 ADVANCED PHOTODETECTORS TECHNOLOGIES}

1172302 T2SL focal planes for compact remote sensing instruments (Keynote Paper) [11723-19]

$1172303 \quad$ Novel IR photodetectors and energy harvesting devices (Invited Paper) [11723-1]

1172305 eSMR and MMR gain-based photodetectors in type-Il superlattices: past, present, and future (Invited Paper) [11723-20]

1172306 Sensitivity improved themal infrared sensorcell applying the heat insulating phononic crystals (Invited Paper) [11723-3]

1172307 Development of HD-format 1280 x 1024 InAsSb-on-GaAs two-color MWR/ MWR and SWR/ MWR focal-plane array technology [11723-4]

$1172308 \quad$ Novel 8-inch wafer scale process for low-cost production of back side illuminated (BSI) imaging sensors [11723-5]

11723 OA Geometry and material optimization of long wave infrared Seebeck nanoantennas [11723-7]

SESSION 2 IR TECHNOLOGIESAND APPUCATIONS

11723 OB Longwave infrared tunable notch filters (Invited Paper) [11723-21]

11723 OD Magnetic nanoparticles response to low frequency induction heating in rigid matrices [11723-9]

11723 OE Infrared complex reflectance micro-spectroscopy [11723-10]

11723 OG Motion amplification: a camera-based full field vibration technique [11723-12]

$11723 \mathrm{OH}$ A comparative evaluation of the fast optical pulse response of event-based cameras [11723-13]

11723 0] Towards high-performance resonant filter forthe long-wave infrared band: fabrication and characterization of notch filters based on the guided-mode resonance effect [11723-22] 


\section{POSTER SESSION}

11723 OL IR absomtion spectra for isolated PFAS molecules using density functional theory [11723-15]

11723 OM Bessel acoustic lens for large volumetric photoacoustic mic roscopy [11723-16] 